\title{
UNIVERSITYOF
}

FORWARD

THINKING

WESTMINSTER用

WestminsterResearch

http://www.westminster.ac.uk/westminsterresearch

\section{K. Rajagopal on making films for and on the ethnic minority in} Singapore

$\mathrm{Ng}, \mathrm{H}$.

(c) Ng, H., 2020.

The definitive, peer reviewed and edited version of this article is published in Asian Cinema, 31 (1), pp. 139-142:

https://doi.org/10.1386/ac 000197

The WestminsterResearch online digital archive at the University of Westminster aims to make the research output of the University available to a wider audience. Copyright and Moral Rights remain with the authors and/or copyright owners. 


\section{Interviews \\ How Wee NG \\ Interview}

\section{Interview: K. Rajagopal on making films for and on the ethnic minority in Singapore}

\section{Interview by How Wee NG}

How Wee Ng (https://orcid.org/0000-0002-8281-9081) is postdoctoral fellow at the University of Westminster, London. He has taught at the University of Hull and SOAS, University of London. Research interests range from censorship in Sinophone cinema and television and issues of cultural intervention in Singapore theatre. Selected publications include monograph Drama Box and the Social Theatre of Singapore: Cultural Intervention and Artistic Autonomy (Nanyang Technological University Chinese 2011), book chapter 'Rethinking censorship in China: The case of Snail House (Woju)' (Routledge, 2015), and forthcoming articles on Sinophone intercultural theatre, Mainland Chinese television and Singapore theatre.

Contact: School of Humanities, University of Westminster, 309 Regent Street, London W1B 2HW, UK.

E-mail: h.ng@westminster.ac.uk 
(GHA), Hong Kong Film Awards (HKFA) and Golden Rooster Awards (GRA), and what they might signify for Singapore cinema, especially for a nation that is predominantly ethnic Chinese. Compared to the number of Singapore Chinese-language films produced in the last two decades, there have been considerably less Indian-language productions. K. Rajagopal's 'A Yellow Bird' (2016) alongside two other Tamil films, namely Eric Khoo's 'My Magic' (2008) and T. T. Dhavamanni's 'Gurushetram - 24 Hours of Anger' (2010) offer critical takes on the vicissitudes of Singapore Indians struggling with issues such as socioeconomic inequality and racial prejudice in a booming Chinese-majority city-state.

K. Rajagopal is best known for his feature film, A Yellow Bird, which premiered at the Cannes Film Festival in 2016. Rajagopal is one of the most frequently commissioned filmmakers in Singapore. Following his wins at the Singapore International Film Festival's Special Jury Prize for three consecutive years with I Can't Sleep Tonight (1995), The Glare (1996) and Absence (1997), he has gone on to make films, including Brother (1999) and The New World for the launch of the 'Digital Homeland Series' at the National Museum of Singapore, and Timeless (2011) which won Best Cinematography and Best Editing at the Singapore Short Film Awards in 2011. He was also involved in two omnibus projects, Lucky 7 (2008) which premiered at the Rotterdam Film Festival and 7 Letters (2015), which commemorated the 50th anniversary of Singapore's independence.

Interview date: 28 August 2017

How Wee Ng (HWN): What do you think of the media and film representation of minor ethnic groups and language in Singapore, generally? 
K. Rajagopal (KR): It is quite obvious that there are not that many films that represent the minority ethnic groups. Very often we only see an Indian or Malay actor in character or supporting roles in films to represent our multi-racial society or to give a sense of realism to the film. Well, the audience largely comprise of the Chinese majority and therefore I would not fault the situation. I just wish that more ethnic minority stories will be produced or told as they are relevant and crucial in shaping the history and exploring the diversity that exist in the country. More minority filmmakers must not shy away and continue to persevere to tell their stories and not worry too much about the box office. The media should support more of these local ethnic films as well especially if it is well told. It is almost a moral responsibility since we live in a very diverse and a multi-racial society especially with more new Indian and Chinese nationals who have made Singapore home in recent years.

$\boldsymbol{H W N}$ : Indeed, you have mentioned on several occasions that it is important to feature the ethnic Other in your films. In a Today interview on 18 May 2016, you stated that 'We do not live in a homogenous society but a multicultural one, and oftentimes, the voice of the minority goes unheard or gets lost. ...I wanted to present an extreme situation in order to see the consequences of that particular individual's life in a civic society'. Would it be right to say that as a Singapore director from an ethnic minority background, this is the main reason you focus on the representation of ethnic Indian characters in your films? I understand that you've talked about racial discrimination in Singapore on many occasions, but would you be able to talk a little more about this?

KR: Yes I was compelled to create films about Indians in Singapore right from the start. I went through an identity crisis and was in denial of my own Indian roots. I was often 
teased at a young age about certain superficial issue likes having oil on my hair or the way I pronounced certain words or when I spoke in my mother tongue. It scarred me for a while and I wanted to be Chinese during my growing up years as a teenager. It was only when I was not even recognized as a Singaporean and seen as Indian from India and often asked the question where I am from during the influx Indian foreign migration into the country in the early 1990 s that I decided to act on it. I was also a frustrated actor as there were very few parts for minority ethnic actors although I must say that I learnt a lot from the plays I acted in. All these reasons made me feel stronger about telling the stories of the Indian minority even more and I set myself the task of making films about them. I still feel it is important to create a voice for the minority habits community through my own personal stories. Racism does exist in our society but it is not overt. It is simmering under the skin and sometimes that can be quite dangerous as it might surface unexpectedly. That is why films can help bridge the gap and each other to gain insight into each other's habits, culture and history.

HWN: How do you perceive GHA's standing among Singapore directors, for example in terms of media coverage and perceived prestige?

KR: Well I think it is a great platform and Singapore directors have done well for themselves in that platform and it is definitely very encouraging for emerging filmmakers.

The significant media coverage for a GHA and the prestige attached is definitely more evident as we have a large majority audience who are interested in the film industry and the film personalities from the East. The region produces very good films and has had a long history of producing both good commercial and non-commercial films. It has 
also been an industry where great filmmakers who have shaped Chinese cinema had come from by challenging the minds of audiences over various generations.

HWN: Have you ever submitted your works to Indian-language film festivals?

KR: Yes, I have. A Yellow Bird has travelled in the film festival circuit and had its premiere in Goa last year. It also went to the Busan International Film Festival in South Korea and the Pacific Meridian International Film Festival in Vladivostok, Russia. We have also received invitations to several other film festivals around the world. My short films have been screened in Delhi and I have sent my films to platforms that promote the Indian language in the region as well.

HWN: Based on your understanding, what is the implication of winning a GHA as opposed to winning awards at Singapore International Film Festival Award, or awards at Indian-language film festivals around the world?

KR: Winning any award for your work is always seen as good thing; it does not matter what the platform it is or whether it is prominent or not. I am very proud of the Singapore International Film Festival and without the festival I might not have had the impetus to carry on making films. The awards form the festival definitely encouraged me to carry on telling my stories. Well, I might submit a work to GHA if given the opportunity. Winning an award from GHA is equally welcomed as it will only help create more awareness about Singapore's multi-racial ethnic profile and talents.

HWN: Unfortunately, GHA has certain criteria that may make it less straightforward for a non-Chinese filmmaker. I'd like you to look at the criteria and tell me your thoughts.

Language and Crew

All submission [sic] are required to meet either of the following conditions to be eligible: 
01. Chinese languages (including official and vernacular languages used in the Chinese-speaking territories of the world; dubbing not included) should be used as dialogue in no less than half of the film. Films with no dialogue MUST meet condition 02 as below.

02. The director AND at least five members of the main creative crew must be of Chinese origin. The main creative crew shall be from either one of the following categories: leading actor, leading actress, supporting actor, supporting actress, original/adapted screenplay, cinematography, art direction, film editing, original film score, and sound effects. The eligible main creative crew must comprise at least five of the above categories ('Guidelines').

In short, the GHA is focused on the promotion of Chinese cinema, and looking at the criteria, and coming from someone who believes strongly in the representation of minority voices (especially in the context of a Chinese-majority Singapore), do you think the criteria runs against your artistic principles?

KR: Yes, possibly but every organization and academy like the GHA may have its own prerogative and I can understand that. It is set up in a country that is more homogenous as well say compared to Singapore. Then we may have to fault many other academies that promote say just Indian culture in India. Racial equations in a country and perhaps an arts academy cannot really be compared in this case.

$\boldsymbol{H W N}$ : There have been suggestions that mainstream media such as the Singapore English national daily Straits Times was favouring Ilo Ilo's GHA success over its win of the Camêra d'Or at Cannes. Do you agree, and why? 
KR: Well I don't think so and can't really comment as I did not consciously feel it or observe rather.

$\boldsymbol{H W N}$ : Given the prolific media coverage which GHA receives (in both English and Chinese mainstream media) in Singapore, would this not bolster the already privileged position of Chinese filmmakers by virtue of their ethnicity, thereby exacerbating the marginalization of non-Chinese filmmakers?

KR: Basically, it would be good if GHA was more inclusive but let's see it might happen as we evolve further and our boundaries are less defined by race.

How Wee Ng has asserted his right under the Copyright, Designs and Patents Act, 1988, to be identified as the author of this work in the format that was submitted to Intellect Ltd. 